\title{
Retrospective study of the situation of Brazilian countryside schools and conceptions of teachers of rural public schools in the municipality of Itapuranga, Goiás, Brazil
}

Letícia de Sousa Silva ${ }^{1}$, Jonathas Rodrigues Siqueira Costa $^{2}$, Liliane de Sousa Silva ${ }^{3}$, Carla Rosane Mendanha da Cunha $^{4}$

${ }_{1}^{1}$ Secretaria Municipal de Educação de Anápolis - GO. Rua Professor Roberto Mange, 152, Vila Santana. Anápolis - GO. Brasil. $^{2,3,4}$ Universidade Federal de Goiás - UFG.

Author for correspondence: ssleticia12@gmail.com

\begin{abstract}
The aim of this study was to understand the underlying context of the countryside education according to the teachers in the municipality of Itapuranga-GO, as well as retrospective analysis of the closure of the countryside schools and the number of enrollments. Data collection included application of a questionnaire about teachers' conceptions and concepts regarding the structure, transportation, professional training and transformations in education in the school of the countryside in which they work. The survey with the teachers was carried out in August 2017 and the search for the number of enrollments and schools was carried out on the databases of QEdu and IBGE (Brazilian Institute of Geography and Statistics). Municipality of Itapuranga has two rural municipal schools, the Betel Municipal School and Serra Dourada Municipal School, containing 08 and 03 teachers, respectively. Only 09 teachers agreed to participate in this study, being 5 of the female and 4 of the male gender. The age of teachers varied from 30 to 50 years. They all have degrees in areas such as Pedagogy, Letters (English), Mathematics and/or History, and only has a complementary course in the field of countryside school, which is in Family Farming. It was verified that the management model, the contents, the projects and the training of teachers of the countryside schools of the municipality follow the same Pedagogical Political Project (PPP) of the urban schools and that there is not an effort of the state and the professionals to adapt the rural schools within established principles.
\end{abstract}

Keywords: Rural school, Countryside education, Training of professionals, School enrollments, Closing schools. 


\title{
Estudo retrospectivo da situação das escolas do campo brasileiras e concepções dos professores de escolas públicas rurais no município de Itapuranga, Goiás, Brasil
}

\begin{abstract}
RESUMO. O objetivo deste estudo foi compreender o contexto que perfaz a educação do campo segundo os professores, no município de Itapuranga-GO, bem como análise retrospectiva quanto ao fechamento de escolas do campo e número de matrículas. A coleta de dados contou com a aplicação de um questionário sobre concepções e conceitos dos professores quanto à estrutura, o transporte, a formação profissional e as transformações na educação na escola do campo em que trabalham. A pesquisa junto aos professores ocorreu em agosto de 2017 e quanto ao número de matrículas e escolas foi realizada no site QEdu e IBGE (Instituto Brasileiro de Geografia e Estatística). No município de Itapuranga tem duas escolas municipais rurais, sendo uma a Escola Municipal Betel e a outra a Escola Municipal Serra Dourada, contendo 8 e 3 professores, respectivamente. Aceitaram participar da pesquisa somente 9, sendo 5 do gênero feminino e 4 do masculino. A idade dos professores varia de 30 a 50 anos. Todos têm graduação em áreas como pedagogia, letras/inglês, matemática e/ou história, e somente um professor tem um curso complementar dentre as áreas visadas pela educação do campo que é agricultura familiar. Constatou-se que o modelo de gestão, os conteúdos, os projetos e a formação de professores das escolas rurais do município seguem o mesmo Projeto Político Pedagógico (PPP) das escolas urbanas e que não há um esforço do poder público e nem dos profissionais para adequar a escola do campo dentro dos princípios estabelecidos.
\end{abstract}

Palavras-chave: Escola Rural, Educação do Campo, Formação dos Profissionais, Matrículas Escolares, Fechamento de Escolas. 


\section{Estudio retrospectivo de la situación de las escuelas de campo brasileñas y concepciones de profesores de escuelas públicas rurales en el municipio de Itapuranga, Goiás, Brasil}

RESUMEN. El objetivo del estudio era comprender el contexto que conforma la educación rural según los docentes, en el municipio de Itapuranga-GO, así como análisis retrospectivos del cierre de escuelas en el campo y el número de inscripciones. La recopilación de datos incluyó la aplicación de un cuestionario sobre las concepciones y conceptos de los docentes sobre la estructura, el transporte, la capacitación profesional y las transformaciones en la educación en la escuela en el país donde trabajan. La investigación con los profesores se realizó en agosto de 2017 y la búsqueda del número de inscripciones y escuelas se realizó en el sitio web de QEdu y IBGE (Instituto Brasileño de Geografía y Estadística). En el municipio de Itapuranga hay 2 escuelas municipales rurales, una es la Escuela Municipal Betel y la Escuela Municipal Serra Dourada, con un total de 8 y 3 maestros, respectivamente. Solo 9 aceptó participar en la investigación, 55.5\% $(\mathrm{n}=5)$ de mujeres y $44.5 \%$ $(\mathrm{n}=4)$ de hombres. La edad de los maestros varía de 30 a 50 años. Todos tienen títulos en áreas como pedagogía, letras/inglés, matemáticas y/o historia, y solo un maestro tiene un curso complementario entre las áreas a las que apunta la educación rural, que es la agricultura familiar. Se encontró que el modelo de gestión, el contenido, los proyectos y la formación de docentes de las escuelas rurales del municipio siguen el mismo Proyecto Pedagógico Político (PPP) de las escuelas urbanas y que las autoridades públicas o los profesionales no hacen ningún esfuerzo para adaptar la escuela rural dentro de los principios establecidos.

Palabras clave: Escuela Rural, Educación Rural, Formación Profesional, Inscripción Escolar, Cierre de Escuelas. 


\section{Introduction}

Education is key to wisdom to fight for human rights and social justice. Education varies in cultures and social structures because it does not have a specific model for all cultures (Brandão, 1998):

Education also takes place where there is no school and everywhere where there may be networks and social structures for transferring knowledge from one generation to another, where the shadow of some formal and centralized teaching model has not yet been created. The education learns from man to continue the work of life. The life transports from one species to another, within the history of nature, and from one generation to another of living, within the history of the species, the principles through which life itself learns and teaches about living and evolving in each type of being. (Brandão, 1998, p. 13).

According to Venâncio Filho (1944, p. 203), the school becomes essential from the moment that it incorporates systematized teaching with differentiated activities from out-of-school, where it can learn to read, write, obtain mastery of calculations, among others, thus expanding its knowledge.

In Brazil, currently, the Law of Guidelines and Bases of Education (LDB) $\mathrm{n}^{\circ} 9.394$ that was promulgated on December 20, 1996, in its article 1 emphasizes that: "Education encompasses the formative processes that develop in family life, in human coexistence, at work, in educational and research institutions, in social movements and civil society organizations and in cultural manifestations", being based on the principle of the universal right to education for all, so that through it the individual becomes aware to use it in its evolution.

According to the Brazilian Federal Constitution, education is ensured for the whole society and recognized as an efficient mechanism of transformation of people, thus education is a right of all and a duty of the State according to Article $n^{\circ}$ 205 of the Federal Constitution (Brasil, 2007).

The study of Souza, Silva, Clemente (2015), highlights the way the population of the countryside has been seeking its own education, being united to the ways of organizing the life and culture of the peoples who live in the countryside. Decree $n^{\circ} 7.352$ of November 4, 2010, established a series of definitions and measures that seek to contemplate a policy aimed at the peoples of the countryside. The countryside school is defined as:

Article $1^{\circ} \S 1^{\circ}$ (II): The one located in a rural area, as defined by the Brazilian Institute of Geography and Statistics Foundation - IBGE, or that 
located in an urban area, as long as it predominantly serves rural populations. (Decree $\mathrm{n}^{\circ} 7.352,2010$, p. 2).

In the 1990s, the movement "For Rural Education" started in Brazil, an struggle of the people of the countryside for public policies that guarantee their right to education, and for an education from and in the countryside (Kolling, Cerioli \& Caldart, 2002). It was guided by social movements, the main one being the Landless Movement (MST), followed by the Movement of People Affected by Dams (MAB), the Peasant Women's Movement (MMC), the Movement of Small Farmers (MPA), the Confederation of Agricultural Workers (CONTAG), the Rural Workers' Movement, the Education Network of the Brazilian Semi-Arid (RESAB) and the Pastoral Land Commission (CPT) (Munarim, [s.d.]).

Arroyo (2004) described that the rural area is different from the urban one and that there is a need to create public policies that improve the education of the countryside and provide quality standards to the people of the countryside. Students of the countryside have more difficulties to access educational institutions due to distance, precarious conditions of school transport, displacement of teachers from the urban to the countryside area, lack of basic and technological infrastructure, as well as subjects compatible with the reality of countryside. According to INEP (National Institute of Educational Studies and Research), students from the Brazilian rural schools have a lower performance in the test of the National System of Evaluation of Basic Education (Saeb) than students from urban schools. The right to an education in the rural community appropriate to its sociocultural diversity is based on Article 28 of Law $n^{\circ} 9.394 / 96$ of the LDB (Brazilian National Education Guidelines and Bases Law):

Article 28. In the provision of basic education for the rural population, the education systems will promote the necessary adaptations to their adequacy to the peculiarities of rural life and each region, especially: I Curriculum content and methodologies appropriate to the real needs and interests of rural students; II - Own school organization, including adequacy of the school calendar to the stages of the agricultural cycle and climate conditions; III - Adaptation to the nature of work in the rural area.

Countryside education provides an opportunity for understanding of a sustainable development and the better quality of life, and the essential that is to enable educational projects and organization of pedagogical exercise in countryside schools in Brazil (Brasil, 2011). According to Oliveira and Macêdo (2009), countryside schools have the role of strengthening and improving the life and reality of the rural community, struggling 
to educate the child of rural areas. In view of the rights of a citizen to the quality of education, infrastructure, qualified teachers and appropriate materials, it is necessary to recognize how fundamental the rural environment is, offering a quality education to those who supply the population. Historically, Brazilian educational policy has not prioritized or contemplated the needs and reality of the peoples of the countryside, as the Brazilian Ministry of Education (MEC) states in the document:

It turns out, therefore, that historically there was no commitment of the State to implement an educational system appropriate to the needs of the rural populations. The Brazilian State has omitted: (1) in the formulation of specific political and pedagogical guidelines for rural schools; (2) in the financial allocation that would enable the institutionalization and maintenance of a quality school; (3) in the implementation of an effective policy of initial and continued training and appreciation of the teaching career in rural area. (MEC, SECAD, 2005).

In the current scenario, reflecting on the insertion and presence of schools in countryside means thinking about nature, the maintenance of space and families, family farming and rural succession, the strengthening of the culture and traditions of the countryside. The education should be locally tailored, as Cardart (2002, p. 26) points out that: "people have the right to an education thought from their place and with their participation, linked to their culture and their human and social needs". The process of globalization has permanently interfered in families living in rural areas, due to the incentive to monoculture and agriculture, lack of investments in the schools of the countryside, which may have discouraged parents, children and young people to remain in the countryside. As a result, rural evasion becomes increasingly greater, especially among the younger ones who go to urban centers in search of new opportunities for personal growth, discrediting the potential of the rural areas (Mazur, 2015).

The objective of this study was to evaluate the conceptions of teachers who work in basic education, in two schools of the countryside of the municipality of Itapuranga (Goiás), as well as to conduct a retrospective study on the closure of rural schools and number of enrolments in rural and urban schools in Brazil and Goiás from 2010 to 2018.

\section{Methodology}

The present study is exploratory and descriptive, with a qualitative and quantitative approach to the data, based on the method of Lakatos and Marconi (1993). The study was carried out in the 
city of Itapuranga, which is located in the

São Patrício Valley, northwest of the State of Goiás, $155 \mathrm{~km}$ from the capital Goiânia. Quantitative data were obtained from the database of IBGE, for demographic data of the municipality and QEdu, in order to evaluate the number of enrollments and number of countryside schools from 2010 to 2018 in the public education system in Brazil, in the state of Goiás and in municipality of Itapuranga.

The evaluation of teachers' perception was conducted through a questionnaire containing 6 questions, being 2 close-ended and 4 open-ended questions. Data collection was carried out on August 7 and 8, 2017, in two countryside schools, the Betel Municipal School and Serra Dourada Municipal School. Both are from basic education with elementary education I and II. The teachers from both schools were informed about the objectives of the research, the advantages, the procedures that would be used, and the guarantee of confidentiality of the data involved in the research. Teachers had freedom to refuse to participate or withdraw its consent in any stage of the research without any penalty or prejudice. Those who accepted signed the document statement Free and Informed Consent.

\section{Results and discussion}

\section{The countryside schools in Brazil and in the state of Goiás}

In Brazil, according to the last National Institute of Educational Studies and Research Anísio Teixeira (INEP, 2016) $33.9 \%$ of Brazilian schools were in countryside areas (Figure 01).

Figure 01 - Percentage of schools in countryside and urban areas in Brazil in 2016.

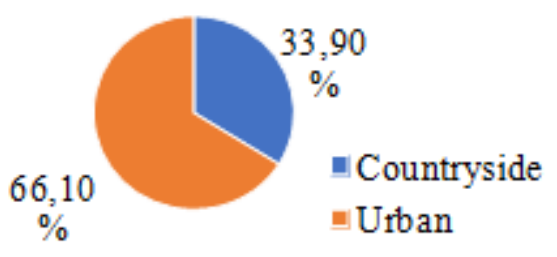

Source: Adapted from INEP, 2016.

This number was already more significant in 2010, in which countryside schools represented $49.63 \%$ of the total number of schools in Brazil. There was a reduction in the number of countryside schools also in the state of Goiás, with $18.54 \%$ in 2010 and $15.01 \%$ in 2016 , a reduction of $3.53 \%$ in the number of schools. Table 01 shows the number of countryside and urban schools in Brazil and in the state of Goiás per year (20102018). 
Silva, L. S., Costa, J. R. S., Silva, L. S., \& Cunha, C. R. M. (2020). Retrospective study of the situation of Brazilian countryside schools and conceptions of teachers of rural public schools in the municipality of Itapuranga, Goiás, Brazil...

Table 01 - Total number of urban and countryside schools in Brazil and the State of Goiás from 2010 to 2018.

\begin{tabular}{|ccccc} 
Year & \multicolumn{2}{c}{ Brazil } & \multicolumn{2}{c}{ Goiás } \\
& Urban & Countryside & Urban & Countryside \\
$\mathbf{2 0 1 0}$ & 79,934 & 78,776 & 2,806 & 639 \\
$\mathbf{2 0 1 1}$ & 80,486 & 75,678 & 2,817 & 603 \\
$\mathbf{2 0 1 2}$ & 80,999 & 73,584 & 2,828 & 506 \\
$\mathbf{2 0 1 3}$ & 81,665 & 70,219 & 2,859 & 573 \\
$\mathbf{2 0 1 4}$ & 82,144 & 66,904 & 2,890 & 562 \\
$\mathbf{2 0 1 5}$ & 82,627 & 64,091 & 2,928 & 542 \\
$\mathbf{2 0 1 6}$ & 83,278 & 62,369 & 2,966 & 524 \\
$\mathbf{2 0 1 7}$ & 84,662 & 60,064 & 3,033 & 515 \\
$\mathbf{2 0 1 8}$ & 84,344 & 56,954 & 3,030 & 502 \\
& \multicolumn{3}{c}{ Source: Adapted from QEdu, 2019. }
\end{tabular}

It can be seen that from 2010 to 2018, 21,822 countryside school units were closed in Brazil and 4,410 urban schools were opened. In Goiás, 137 countryside schools were closed and 224 urban schools were opened. According to Souza et al. (2016), in 2000 there were 1,824 units of countryside schools, which reduced to 542 units in 2015, placing the State of Goiás among those that most closed countryside schools in Brazil.

In this process of closing the countryside schools, it is not only school units that close, but also one of the main elements for strengthening family farming, the education from and in the countryside. These facts contribute to peasant students to lose their identity with their territory and migrate to urban areas contributing to rural evasion. However, it can be seen that the number of enrollments in urban and countryside public schools has not varied considerably in recent years in Brazil (Figure 02), however in 2018 the number of enrollments in urban schools decreased by $26 \%$ (from $34,970,543$ enrolments in 2017 to $25,667,542$ in 2018). 
Figure 02 - Total enrollments in the public education system from 2010 to 2018 in urban and countryside school units in Brazil.

\section{Total enrollments in the public education system in Brazil}

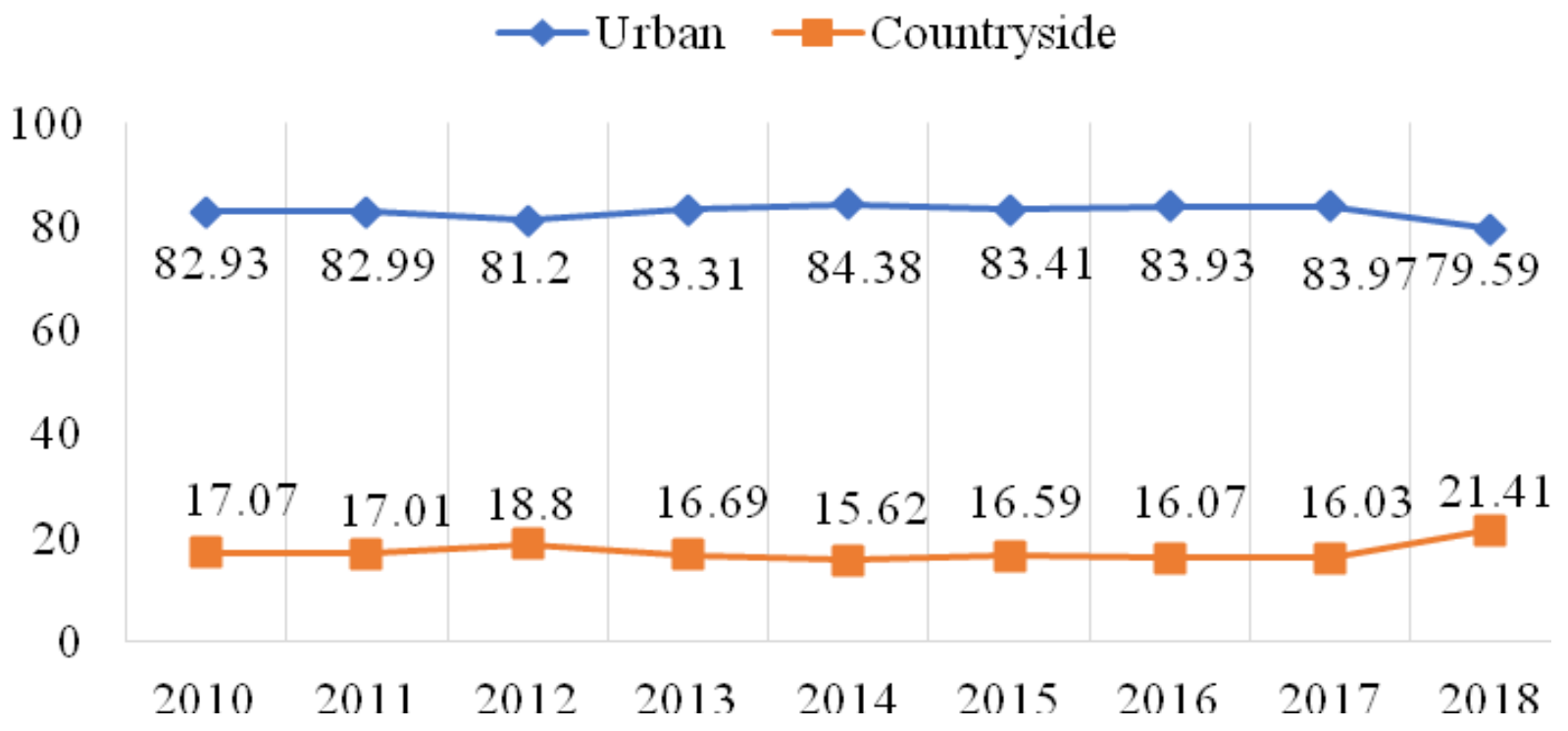

Source: Adapted from QEdu, 2020.

The concentration of enrollment in the urban area is consistent with the more general distribution of the population, most of which are in urban areas, as revealed in the IBGE census of 2010. At the same time, there is a contingent of students moving from the rural area to study in urban schools and this factor may be considered in this distribution. This displacement may be due to the programs implemented by the federal government, such as school transport offered by the State or municipal public authorities (Brasil, 2014).

In 2004, the Law $\mathrm{n}^{\circ} 10.880$ created the National Program to Support School
Transportation (PNATE), which aimed to ensure access and permanence of students living in rural areas in basic education of public schools in the country (Brasil, 1996). Another program is the Way to School (Brasil, 2007) that provided a credit line for the acquisition, by states and municipalities, of buses, minibuses and boats to improve students' access to urban and countryside schools (FNDE, 2016; Barsanuf et al., 2016). According to Barsanuf et al. (2016), the studies coordinated by MEC/FNDE and the University of Brasília pointed out that "in Brazil more than 4.8 million students of basic education in the public system who 
live in rural areas depend on daily transportation to go to school".

Another common problem is the prejudice that the students who come from rural areas suffer in urban schools, strengthening the idea that living in the countryside influences a lower level of learning, increasing differences in educational development between rural and urban students. Vilela (2014) evaluated students from the city of Rio Preto, state of São Paulo, regarding the prejudice issue, and $84.2 \%$ revealed that they had already witnessed situations of prejudice in the school environment. It can be seen that urban existence was expressed, culturally, in the construction of negative stereotypes about the rural residents and even the parents themselves encourage their children to leave the countryside to seek better living conditions.

\section{Demographic and structural aspects of the countryside school units in the municipality of Itapuranga-GO}

The city of Itapuranga is located in the St. Patrick's Valley, northwest of the State of Goiás, $155 \mathrm{~km}$ of the capital Goiânia. It has the Cerrado biome, an area of 1,276,479 $\mathrm{km}^{2}$ (Figure 03), a population according to IBGE (2010) of 26,125 inhabitants with a population density of 20.47 (inhabitant $/ \mathrm{km}^{2}$ ), of which 12,922 were men and 13,203 were women. The economy of the municipality is based on agriculture and livestock of small farms, which is due to the configuration of the municipality in the process of land occupation through the policy of the New State, in the Program of the March to the West, and with the National Agricultural Colony of Goiás - CANG, located in the municipality of Ceres, near Itapuranga (Costa, S/D). Currently, the municipality has 18 schools, 12 are situated in the city, 4 in districts (Lages, Diolândia, Vila São José and Cibele) and 2 in rural area (see Figure 03). 
Figure 03 - Location of the municipality of Itapuranga, indicating urban and rural area, the districts and countryside schools within the limits of municipality.

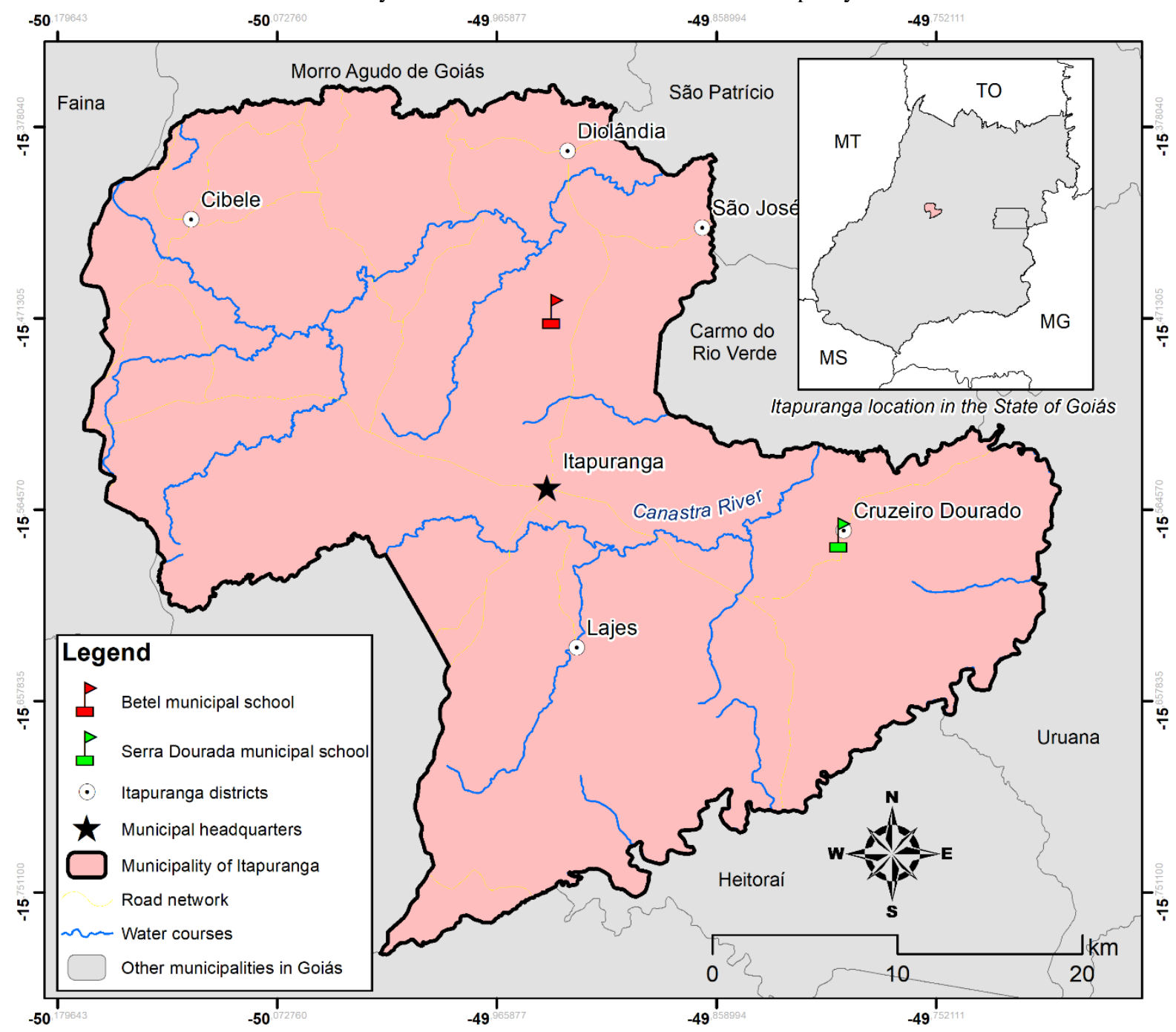

Source: Author, 2017.

According to the last IBGE census (2010), in the municipality the population living in the urban area was 21,235 and in rural was 4,890 , totaling 26,125 . Regarding the number of children living in rural area, in early childhood and basic education, it can be seen that $4.2 \%(n=210)$ were aged 0 to 4 years, $7 \%(n=343)$ from 5 to 9 years, $7.9 \%(n=382)$ from 10 to 14 years, $5.7 \%$ $(\mathrm{n}=281)$ from 15 to 19 , and $75.2 \%$ over 20 years (IBGE, 2010). Therefore, 24.8\% $(n=1,216)$ were of school age of early childhood or basic education and could have studied in countryside schools, however the QEdu data of 2020 showed that the number of enrollments in the countryside schools was 181 (see Table 02). 
Silva, L. S., Costa, J. R. S., Silva, L. S., \& Cunha, C. R. M. (2020). Retrospective study of the situation of Brazilian countryside schools and conceptions of teachers of rural public schools in the municipality of Itapuranga, Goiás, Brazil...

Table 02 - Number of enrollments in the public system from 2010 to 2018 in the municipality of Itapuranga-GO.

\begin{tabular}{cccc}
\hline Year & Urban & Countryside & Total \\
\hline $\mathbf{2 0 1 0}$ & 4.824 & 181 & 5.005 \\
\hline $\mathbf{2 0 1 1}$ & 4.665 & 146 & 4.811 \\
\hline $\mathbf{2 0 1 2}$ & 4.333 & 147 & 4.480 \\
\hline $\mathbf{2 0 1 3}$ & 4.275 & 153 & 4.428 \\
\hline $\mathbf{2 0 1 4}$ & 4.237 & 170 & 4.407 \\
\hline $\mathbf{2 0 1 5}$ & 4.168 & 150 & 4.318 \\
\hline $\mathbf{2 0 1 6}$ & 4.172 & 150 & 4.322 \\
\hline $\mathbf{2 0 1 7}$ & 4.394 & 128 & 4.522 \\
\hline $\mathbf{2 0 1 8}$ & 4.323 & 159 & 4.482 \\
\hline
\end{tabular}

Source: Adapted from QEdu, 2019.

Many students study in the schools of the districts Vila São José, Diolândia, Cibele and Lages, as it can be seen in Figure 03 that the countryside schools contemplate only the southeast and northeast region of the municipality. There is a decrease in the number of enrollments in both countryside and urban schools, and it can be related to several factors such as the rural evasion of individuals to the city, decrease in the number of children, the modernization of agriculture, the expansion of capitalism focused on agribusiness. It corroborates the IBGE estimate for the municipality in 2017, in which there was a population increase of only $1.7 \%(\mathrm{n}=26,586)$ compared to 2010 .

The migration of rural students to carry out their studies in the urban area is due to the aid of school transport offered by the city hall of Itapuranga, which benefits students from all degrees of municipal or state basic education. Many parents prefer their children to study in the city believing that opportunities and education are better.

There are two countryside schools in the municipality of Itapuranga, one being the Betel Municipal School (EMB), located on the GO-156 highway that connects the city of Itapuranga to the district of Diolândia, $12 \mathrm{~km}$ from the municipality of Itapuranga-GO, in Córrego Grande Farm.

The school has 5 teachers in the initial phases (1st to 5th year) and 5 teachers in the final phases (6th to 9th year), 1 manager and 1 coordinator in the morning and 1 coordinator in the afternoon. Regarding the number of 

schools and conceptions of teachers of rural public schools in the municipality of Itapuranga, Goiás, Brazil...

enrollments in 2017, there were 41 students in the initial years and 40 students in the final years, totaling 91 students, with 7 students in the morning and 9 students in the afternoon who live in the city and study at EMB.

It also had the formation of multigrade classes, in which students of different ages and level of knowledge were brought together due to lack of quorum/enough number of students to form a standard class. Schools with multigrade classes are often located in small rural communities, away from the headquarters of municipalities, in which the population to be served does not reach the contingent defined by the departments of education to form one class per grade (Hage, 2011).
Regarding the physical space the EMB (Figure 04), it has 1 administrative secretariat, 1 teachers' room, 1 video room, 1 deposit, 1 canteen, 1 library, 1 computer laboratory, 5 classrooms and a soccer field. Students have countryside school transport offered by the city hall, by bus and kombi, which facilitates the locomotion for those who live in farms nearby. This school serves students of basic education, elementary school I and II. In the morning period had classes from the 6th to the 9th grade, and in the afternoon, classes from garden I to 5th grade.

Figure 04 - The Betel Municipal School.
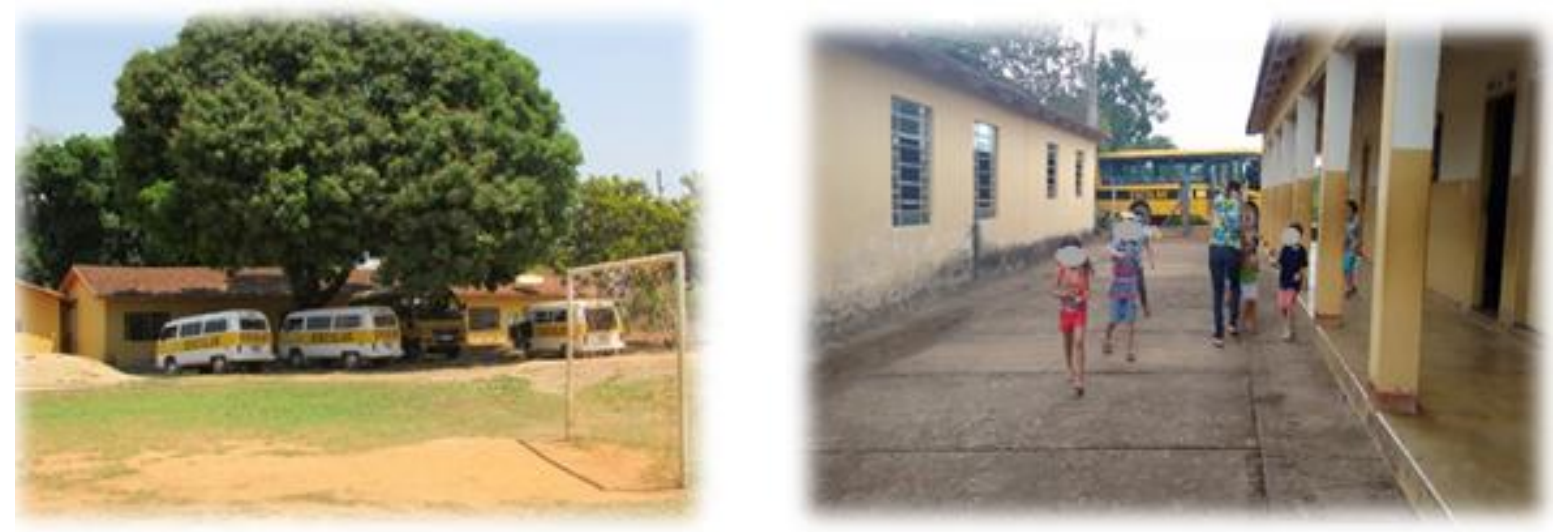

Source: Author, 2017.

The Serra Dourada Municipal School (EMSD) is located at Fazenda Cruzeiro Dourado, $20 \mathrm{~km}$ from Itapuranga, on the GO-230 highway that connects the city of
Itapuranga to Uruana. Around the school there were largeb farms in more numbers than small farms. The students were from low-income families, children of 
Silva, L. S., Costa, J. R. S., Silva, L. S., \& Cunha, C. R. M. (2020). Retrospective study of the situation of Brazilian countryside schools and conceptions of teachers of rural public schools in the municipality of Itapuranga, Goias, Brazil...

employees of farms and small farms, with little schooling. They have rural work as a priority and are often moving to another city, so school dropout and repetition are constant problems in this school.

The EMSD has 1 administrative secretariat, 1 warehouse, 1 canteen, 1 library, 1 computer lab, 3 classrooms, which were multi-grade, 1 for garden I and II, 1 for the 1 st and 2 nd years, and 1 for the 3rd, 4th and 5th years of elementary school I. The school has a teacher working in garden I and II, and two teachers in elementary school I and a principal. In 2017, 39 students were enrolled in the initial years. The school only operates in the afternoon period and the city offers buses and kombis to transport students and staff.

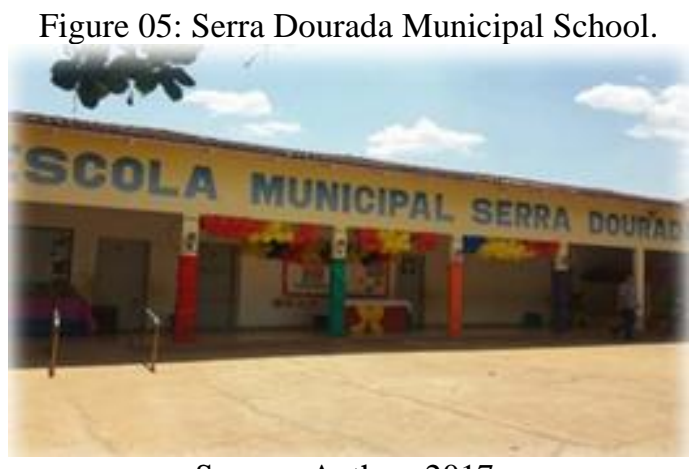

Source: Author, 2017.

Conceptions of the teachers of the countryside school

In both schools (EMB and EMSD), education professionals are residents in the city and they go to work by their own transport or school bus offered by the municipality. In total, the two schools had 11 teachers, 08 from EMB and 3 from
EMSD. Of these, only 09 teachers $(82 \%)$ agreed to participate in this study, being $55.5 \% \quad(n=5)$ female and $44.5 \% \quad(n=4)$ male. The age of teachers ranged from 30 to 50 years, as illustrated in figure 06 . Of these, only one teacher resides in the rural area.

Figure 06 - Age of the countryside school teachers in Itapuranga.

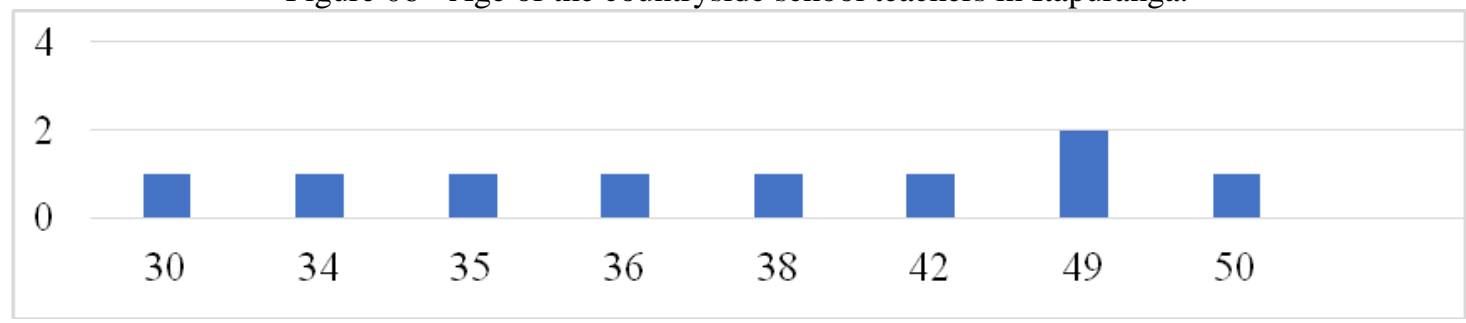

Source: Author, 2017.

\begin{tabular}{l|l|l|l|l|l|l|} 
RBEC & Tocantinópolis/Brasil & v. 5 & e9036 & $10.20873 /$ uft.rbec.e9036 & 2020 & ISSN: 2525-4863 \\
\hline
\end{tabular}


Regarding higher education (figure 07) $34 \%(n=3)$ of the teachers had a degree in Letters (English) with complementation in Pedagogy, 22\% ( $n=2)$ had a degree in Letters (English), 22\% ( $\mathrm{n}=2)$ in Pedagogy, $11 \%(\mathrm{n}=1)$ in History and $11 \%(\mathrm{n}=1)$ in Mathematics. In continuing education, $63.6 \%(\mathrm{n}=7)$ were specialists, being $29 \%$ $(n=2)$ in Neuropedagogy, 14.2\% $(n=1)$ in Socioeconomy of Brazil, 14\% $(n=1)$ in Educational Administration and Brazilian Literature, $14.2 \% \quad(n=1)$ in Mathematics Education, $14.2 \% \quad(\mathrm{n}=1)$ in Portuguese language and Neuropedagogy, and 14.2\% $(\mathrm{n}=1)$ in Research methodology and Extension in Inclusive Education.

Figure 07 - Higher education of teachers of the countryside schools.

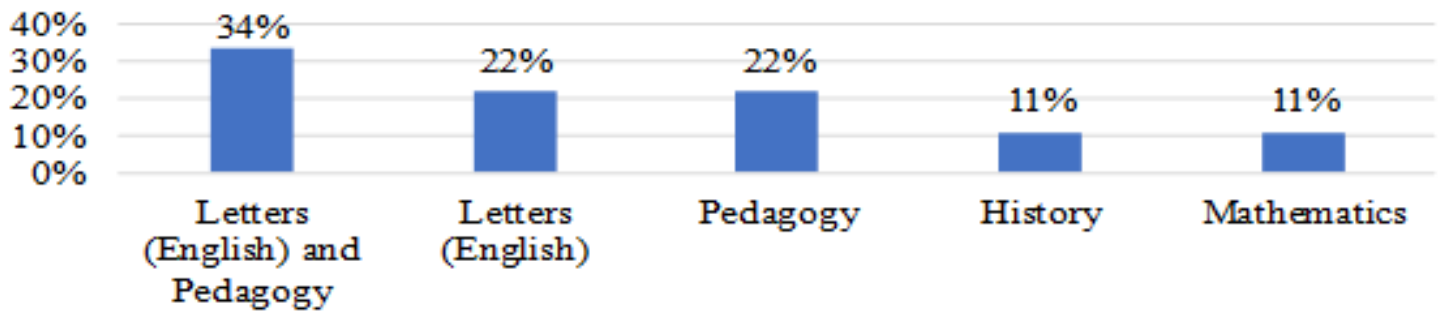

Source: Author, 2017.

It can be highlighted that all the teachers have training in higher education in some degree, and they were qualified to teach. In the study of Rezende, Silva e Silveira (2009), in 14 countryside schools in the municipality of Itapetinga-BA it was observed that only $12.0 \%$ of the teachers were graduates and $63.0 \%$ were attending university, and for a long time teachers had only training in magisterium. The fact that teachers have higher education in Itapuranga-GO, in the areas mentioned (figure 06), may be due to the opportunities of access to higher education in a public university in the municipality and surroundings.

Regarding teaching practice, 66\% $(n=6)$ have more than 3 years of work in a countryside school, thus indicating a good experience (figure 08).

Figure 08 - Time of teaching practice in countryside schools.

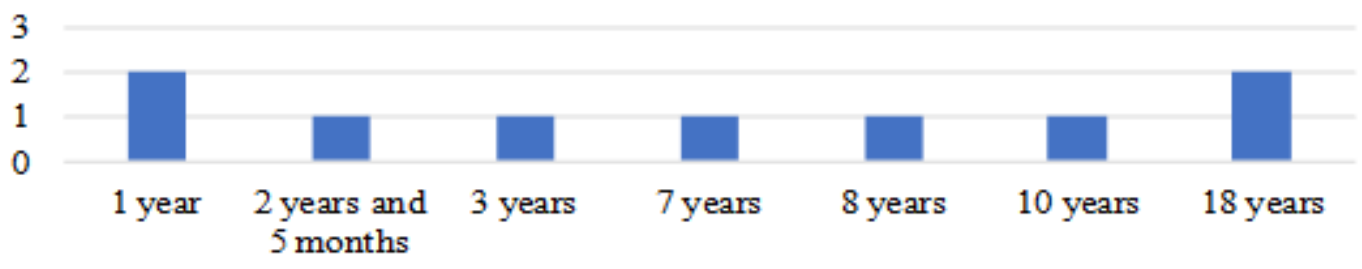

Source: Author, 2017.

\begin{tabular}{|l|l|l|l|l|l|l|} 
RBEC & Tocantinópolis/Brasil & v. 5 & e9036 & $10.20873 /$ uft.rbec.e9036 & 2020 & ISSN: 2525-4863 \\
\hline
\end{tabular}


When asked by the teachers if "Do you have any course (improvement) aimed at countryside education?", only one teacher has a complementary course in the field of countryside school, which is in Family Farming This sentence does not make a valid sense. Consider rephrasing. Many education professionals leave the university without contact with the characteristics of the countryside school. The decree $\mathrm{n}^{\circ}$ 7.352, which provides for the countryside education policy, decrees that

$\S 3$ Public institutions of higher education must incorporate in the pedagogical political projects of their undergraduate courses the processes of interaction between the countryside and the city and the organization of spaces and times of training, in line with the guidelines established by the National Education Council. (Decree $\mathrm{n}^{\circ} 7.352$ of November 4, 2010).

In order to have a quality education for the rural community, the educator must be attentive to the particular traits of being and living in the countryside, such as the practices of family farming, beliefs and values, being fundamental to provide to the countryside man the recognition of its culture.

The Operational Guidelines (2002), in the article $\mathrm{n}^{\circ} 13$, emphasizes the training of teachers in the rural area:
The education systems in addition to the principles and guidelines that guide Basic Education in the country will observe, in the process of complementary standardization of teacher training for the practice of teaching in the countryside schools, the following components: I - a study on the diversity and affective protagonism of children, young people and adults from the rural area in the construction of the social quality of individual and collective life, the region, the country and the world; II - pedagogical proposals that value, in the organization of teaching, cultural diversity and the processes of interaction and transformation of the field, democratic management, access to scientific and technological advances and respective contributions to the improvement of living conditions and fidelity to ethical principles that guide solidarity and collaborative coexistence in democratic societies. (Brazil. Resolution CNE/CEB n. 1, of April 3, 2002, Operational Guidelines for basic education of schools of the countryside, 2002, p. 41).

As evidenced above, teachers should be trained to practice teaching in countryside schools, emphasizing studies on diversity and protagonism, including pedagogical orientations to value the culture and the transformations of the countryside. Evidence shows the relevance of maintaining students' identity. This shows significance of specific preparation. It can be seen the relevance of maintaining the identity of the students, thus there is the indispensability of a specific preparation for these teachers who work in rural communities, being able to develop 
pedagogical practices with actions aimed at these rural populations. According to Arroyo (2007) "a program of training of educators in the rural area must know the centrality of land and territory in the production of life, culture, identities, tradition and knowledge...". Therefore, educators in the rural area should know the reality of the rural population, thus incorporating in the curriculum methods of production of life and culture, focusing on the student from the rural area.

Through questionnaire, the question "What is the differential of the countryside school?" was asked to the teachers, and the answers are transcribed below:

E.D. "To involve the family member in the educational process"'"

A. "The number of students in the classroom, which facilitates the teaching of classes and consequently the assimilation of the contents".".

L. "The interest of students and their discipline"

L.D "Due to the number of students in the classroom, teaching and learning yield more. The culture and education of students are privileges of those who are still "far" from urban area violence.".

V. "Pedagogical material, number of students per room and also distancing from the urban area".

A. "Students are more concerned with teaching learning, greater attention to teaching. For not being influenced by actions * of society."

E. "There is no differential, we follow the curricular matrices of the schools that are in the city".

D.C. "The curriculum is more directed to the reality of the student."
A.F "The countryside school has materials, books and support from both the institution and the city's schools. The classroom has fewer students."

*unreadable

From the observations made about the countryside schools, it can be seen that there is no differential and it follows the same curriculum that the municipality secretariat offers to urban school units as we can observe in the speech of "E":

E. "There is no differential, we follow the curricular matrices of the schools that are in the city".

It is evident that in practice there is no concrete educational policy in the municipality focused on countryside schools. "They are, in fact fragile social institutions regarding teaching, knowledge and organization" (Rezende, Silva \& Silveira, 2009). Arroyo et al. (2004) affirm that "the school in rural areas began to be treated as a residue of the Brazilian educational system ...", thereby the rural population has difficulties in accessing the advances made in 1990 in the recognition and guarantee of the right to basic education, computerization and infrastructure.

According to the answers given by the teachers, it can be seen that they do not take into account the identity of the person in the rural area, the work with the land, its 
culture and its values. Education should not follow the same regular standards in all places and cultures. It is necessary to respect the sociocultural factor and the environment in which the school is inserted, whether in rural or urban area. One of the principles of countryside education in Article $\mathrm{n}^{\circ} 2$ is the "valorization of the identity of the countryside school through pedagogical projects with curricular contents and methodologies appropriate to the real needs of the rural students" (Brasil, 2010).

Regarding the difficulties encountered in teaching classes at the countryside school, the teachers reported that:

E.D. "Effective family participation in school".

A. "The distance traveled every day. The very early departure from home."

L. "Transportation, weather conditions and material resources".

L.D. "Distance and difficult access for both students and teachers."

V. "School transportation and parental accompaniment in school activities".

A."The distance, the resources are hindered $d$ for the proper functioning of the school, the transport of the student is difficult".

E. "Difficulty of access for teachers and students. Time without flexibility for students in the rural area, unique transportation for students from the rural area and the city."

D.C "The difficulty is found in the family to follow, motivate the child in performing the extra activities and during the evaluation period".
A.F "The difficulties are due to the rooms being multi-grade (2 to 3 grades together), before there were up to 5, today we had advances, but the number of students is little".

One of the difficulties is the school transportation, which is the same for both teachers and students from countryside and urban schools, and these students were from the municipality and/or the state. It is noteworthy that there is no flexibility in the schedule for students who study in the countryside school, because of the schedule of students from urban schools, who have to move from the rural area to the city in order to complete their studies in basic education. As we have already shown there were no final years (High School) in the countryside schools and only the EMB has completed elementary school.

Teachers $(66 \%)$ reported difficulties related to access to school, the distance traveled (due to the route of the bus to transport students from the residence to school), schedule and precariousness of transportation. This may be due to the fact that all teachers reside in the city, with this generates a difficulty or even loss of the quality of the educational process, due to the distance itself traveled or the fatigue resulting from the daily "long trips".

Teachers were asked how they classified the support of the public 
Silva, L. S., Costa, J. R. S., Silva, L. S., \& Cunha, C. R. M. (2020). Retrospective study of the situation of Brazilian countryside schools and conceptions of teachers of rural public schools in the municipality of Itapuranga, Goiás, Brazil...

authorities in the permanence/maintenance of the countryside schools (Figure 09), with $78 \%(\mathrm{n}=7)$ reporting as regular, $11 \%$ $(\mathrm{n}=1)$ as good and $11 \%(\mathrm{n}=1)$ as bad.

Figure 09 - Teacher classification regarding the support of the public authorities in the permanence/maintenance of the countryside schools.

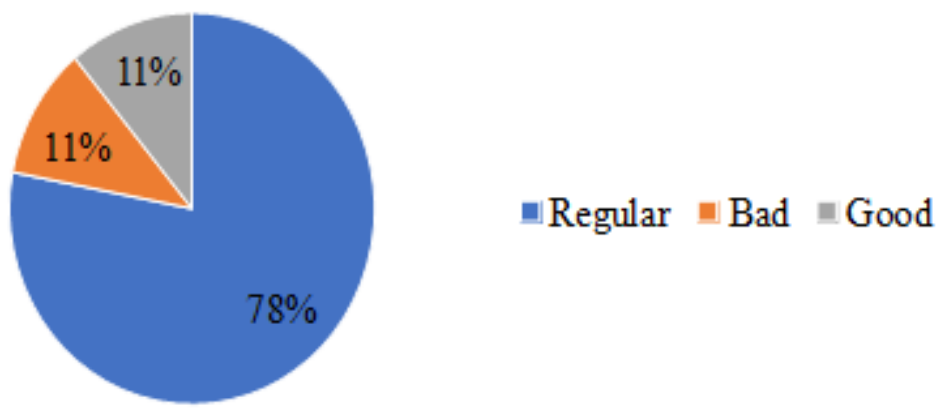

Source: Author, 2017.

Since majority of the teachers $(78 \%)$ considered the support as regular, it is worth mentioning that the support is minimal, through observations and informal reporting of them, the municipality sends rest of activities of urban units, pedagogical materials were scarce, reforms and maintenance of both infrastructure and furniture is carried out with effort of the employees of the school units, the computers were underutilized due to not having access to the internet and books without conditions of use.

When asked about the measures that the countryside school has put in place to motivate children living in rural areas to study at the countryside school and not in the city, the teachers responded,

E.D. "To show the importance of valuing the man of rural area in an expository way"
A. "Attractive activities in line with quality education".

L. "The provision of transportation by the public authorities and the constant search of the faculty for updated and motivating didactic practices".

V. "Quality teaching".

A. "Quality teaching and very attractive".

E. "Priority monitoring for students with difficulties, appreciation of families and cultural values. effort to comply with the full school calendar."

L.D. "Guidance on the importance of studies in the lives of students, in search of a successful future and "fleeing" the hard work of the rural area and also attractive diverse activities".

D.C "We promote diversified, playful activities, we have the computer lab and a library (and toy library) to motivate them.

A.F "Most of the students in this school are children of parents who have already studied in it, they know how much the school values the student, their learning and the coexistence with colleagues and teachers. The school always seeks to innovate, with the use of technologies (computers), sports activities, extra class classes (tours), library, 
playroom, movie room, soccer field, etc.

In the act of motivating, it is worth mentioning that teachers have to contribute to the construction of identity, emphasizing that the man and woman of the rural area have their historical and social value, fought for their rights and contributed to the growth of our nation. The educator Comilo (2008) reports about the difficulties in building the identity of the country man, stating that,

... Often the peasant refuses to assume his identity because, throughout his history, he was regarded as "rude" and inferior. The rural area itself is seen as a space inferior to the city. Class awareness passes through identity awareness, which, in the case discussed here, is that of peasant culture ... (Comilo. 2008, p. 21).

Since not only the man from rural area has the difficulty of assuming his identity, the teacher emphasizes in its speech devalues the work in the rural area, being worrying that the teaching staff of countryside schools does not respect the reality of the rural area. It also can be seen as the lack of rescue of collective memory and peasant culture.

\section{Conclusion}

Education plays a fundamental role in instructing the exercise of rights and duties of the citizen. From the Brazilian Federal Constitution, education became the right of the citizen and the duty of the State and the family. In fact, many public schools do not offer low quality education. Education is in this reality and it is reported that countryside schools do not have structures for the care of students, with absence of adequate material, technologies, teachers without appropriate training, thus precarious teaching.

It is necessary to rethink the countryside school, to seek the guarantee of an education aimed at the rural people. It is necessary to think and build schools from the local reality, where an education is developed linked to the culture of the earth, the reality of the children who attend there, giving a concrete meaning to the study and the day to day, thus dynamic schools consistent with the rural life. For that, it is also necessary to listen to the people from the rural area and learn from its life experiences, work, coexistence and education.

The countryside schools do not offer a study covering the nature and culture of the rural people, in which their experiences are part. Thus, it is crucial to have the commitment of all professionals of countryside schools, to pontificate citizens capable of exercising their obligations. 

schools and conceptions of teachers of rural public schools in the municipality of Itapuranga, Goias, Brazil...

\section{Acknowledgements}

To the State University of Goiás Câmpus Itapuranga, Post-Graduate Program in Education and Agroecology. To the Laboratory of Data Processing and Territorial Management

\section{(LAPROTER/UFRN)}

\section{References}

Arroyo, M. G., Caldart, R. S., \& Molina, M. C. (Org.). (2004). Por uma educação do campo. Petrópolis, RJ: Vozes.

Arroyo, M. G. (2007). Políticas de formação de educadores (as) do campo. Cadernos CEDES, 27(72), 157-176. https://doi.org/10.1590/S010132622007000200004

Brandão, C. R. (1998). O que é Educação. 21. ed. São Paulo: Brasiliense.

Barsanuf, L. M., Wilbert, M. D., Serrano, A. L. M., \& Peña, C. R. (2016). Programa Caminho da Escola: analise da redução do abandono escolar. Brasília: [s.n.].

Brasil. (1996). Congresso Nacional. Lei $\mathrm{n}^{\circ}$ 9.394, de 20 de dezembro de 1996. Estabelece as diretrizes e bases da educação nacional. Recuperado de: http://www.planalto.gov.br/ccivil_03/leis/L 9394.htm Acesso em: 25 de abril de 2016.

Brasil. (2007). Ministério da Educação. Fundo Nacional de Desenvolvimento da Educação. Resolução/CD/FNDE $\mathrm{n}^{\circ} 3$, de 28 de março de 2007. Cria o Programa Caminho da Escola. Diário Oficial da União, Brasília, DF, 04 abr. 2007. Acesso em 18 de março de 2018.
Brasil. (2007). Constituição da República Federativa do Brasil. 40. ed. São Paulo: Saraiva.

Brasil. (2002). Resolução n. 1, de 3 de abril de 2002. Institui Diretrizes Operacionais para a Educação Básica nas Escolas do Campo. Grupo Permanente de Trabalho de Educação do Campo. Brasília/DF: MEC/SECAD, 2002.

Brasil. (2010). Decreto n. ${ }^{\circ}$ 7.352, de 4 de novembro de 2010. Diário Oficial da União, Brasília, DF, 5 nov. 2010. Seção 1, p. 1.

Caldart, R. S. (2002). Por Uma Educação do Campo: traços de uma identidade em construção. In Kolling, E. J., Ceioli, P. R., \& Cardart, R. S. (Orgs.). Por Uma Educação do Campo: Identidade $e$ Políticas Públicas (pp. 25-36). Brasília, DF. Coleção Por Uma Educação do Campo, $n^{\circ} 4$.

Costa, I. S. [s.d.]. Experiências e lutas de memória em Itapuranga-Go. Recuperado de:

https://pos.historia.ufg.br/up/113/o/23_Ism arCosta_ExperienciasELutasDeMemoria.p $\underline{\mathrm{df}}$

Comilo, M. E. S. (2008). A construção coletiva da escola: a Escola Chico Mendes e sua História. In Anghinoni, C., \& Martins, F. J. (Orgs.). Educação do campo e formação continuada de professores (pp. 18-20). Porto Alegre; Campo Mourão: EST Edições; FECILCAM.

CNE. (2002). Diretrizes Operacionais para a Educação Básica nas Escolas do Campo. Resolução n. 1, de 3 de abril de 2002, Câmara de Educação Básica do Conselho Nacional de Educação.

Decreto $\mathrm{n}^{\circ} 7.352$, de 4 de novembro de 2010. Programa Nacional de Educação na Reforma Agrária - PRONERA. Recuperado de: 
Silva, L. S., Costa, J. R. S., Silva, L. S., \& Cunha, C. R. M. (2020). Retrospective study of the situation of Brazilian countryside schools and conceptions of teachers of rural public schools in the municipality of Itapuranga, Goias, Brazil...

http://www.planalto.gov.br/ccivil_03/_Ato 2007-2010/2010/Decreto/D7352.htm.

Acesso em: 25 de abril de 2019.

FNDE. Ministério da Educação. (2016). Fundo Nacional de Desenvolvimento da Educação. Guia do Transporte Escolar. Recuperado de: http://www.fnde.gov.br/arquivos/category/ 131-transporte-escolar. Acesso em: $25 \mathrm{de}$ março de 2019.

IBGE. (2010). Censo Demográfico 2010. Recuperado de: https://7a12.ibge.gov.br/vamos-conhecero-brasil/nosso-povo/caracteristicas-dapopulacao. Acesso em: 25 de março de 2019.

INEP. (2016). Instituto Nacional de Estudos e Pesquisas Educacionais Anísio Teixeira. Recuperado de: http://portal.inep.gov.br/web/guest/inicio/. Acesso em 14 de maio de 2019.

INEP. (2004). Instituto Nacional de Estudos e Pesquisas Educacionais Anísio Teixeira. Desempenho de estudantes da área rural no Saeb é 29 pontos inferior aos de área Recuperado de: http://portal.inep.gov.br/artigo/lasset_publisher/B4AQV9zFY7Bv/content /desempenho-de-estudantes-da-area-ruralno-saeb-e-29-pontos-inferior-aos-de$\underline{\operatorname{area} / 21206}$

Hage, S. M. (2011). Por uma escola do campo de qualidade social : transgredindo o paradigma (multi) seriado de ensino. $E m$ Aberto, 24(85), 97-113. https://doi.org/10.24109/21766673.emaberto.24i85.\%25p

Kolling, E., Cerioli, P., \& Caldart, R. (2002). Educação do campo: identidade $e$ políticas públicas. Por uma Educação do Campo, n. 4.
Lakatos, E. M., \& Marconi, M. A. (1993). Fundamentos de metodologia científica. São Paulo: Atlas.

Mazur, I. P. (2016). O processo de fechamento das escolas no campo em Itapejara D' Oeste/PR: o caso da Escola Estadual de Lageado Bonito e do Colégio Estadual do Campo Carlos Gomes (Dissertação de Mestrado). Universidade Estadual do Oeste do Paraná, Francisco Beltrão.

MEC. (2005). Secretaria de Educação Continuada, Alfabetização e Diversidade. Referências para uma política nacional de educação do campo: caderno de subsídios. Coordenação: Marise Nogueira Ramos, Telma Maria Moreira, Clarice Aparecida dos Santos. 2 ed. Brasília; MEC; SECAD.

Munarim, A. Movimento nacional de educação do campo: uma trajetória em construção. [s.d.]. Recuperado de: http://31 reuniao.anped.org.br/1trabalho/GT 03-4244--Int.pdf

Oliveira, M. A. A., \& Macêdo, M. M. (2009). Educadores do campo: caminhos e desafios. Recuperado de: file:///D:/Backup\%2024-09-

2017/Desktop/Nova\%20pasta\%20(2)/mari a_afonso_magda.pdf. Acesso em 25 de março de 2019.

QEdu. Recuperado de: http://www.qedu.org.br/brasil/censoescolar? year $=2016 \&$ dependence $=0 \&$ locali zation $=0 \&$ item $=$ Acesso em 25 de março de 2019.

Rezende, C. N. V., Silva, S. L. Da Cunha E., \& Silveira, T. C. (2009). Percepção ambiental e a prática docente nas escolas do meio rural do município de ItapetingaBA. Revista Eletrônica do Mestrado em Educação Ambiental, 23, 10-12. https://doi.org/10.14295/remea.v23i0.4573 
Souza, T. R., Silva, R. F. G., \& Clemente, E. C. (2015). Um estudo das escolas no campo no município de Jataí - GO. Recuperado de: http://www.enanpege.ggf.br/2015/anais/arq uivos/11/350.pdf. Acesso em 25 de março de 2019.

Souza, E. F., Bibiano, G. L., Abe, T. A. J., Rocha, D. L., \&; Santos, C. B. R. (2016). Panorama do fechamento de escolas no campo do estado de goiás de 2007 a 2015. Formosa - GO. Recuperado de: http://www2.fct.unesp.br/nera/artigodomes /7artigodomes_2016.pdf

Venâncio, F. (1944). A educação nos países da América Latina. Cultura Política, 4(37), 201-4.

Vilela, F. F. (2014). A educação dos jovens caipiras: um estudo sobre o preconceito em jovens de escolas de meio rural para a formação de professores em educação do campo. Rio Preto. Recuperado de: https://repositorio.unesp.br/bitstream/handl e/11449/141640/ISSN2357-7819-20147011-7023.pdf? sequence $=1 \&$ isAllowed $=y$

\section{Article Information \\ Received on April 27th, 2020 \\ Accepted on June 05th, 2020 \\ Published on August, 13th, 2020}

Author Contributions: The author Letícia de Sousa Silva, was responsible for writing, interviewing teachers, analyzing and interpreting the data. Author Jonathas Rodrigues Siqueira Costa, was responsible for the review and translation of the article into English. The author Liliane de Sousa Silva was co-supervisor, participated in field research and writing, data analysis and review of the article. The author Carla Rosane Mendanha da Cunha, was the teacher adviser, collaborating with the execution and revision of the work. All authors were responsible for approving the final version of the manuscript.

Conflict of Interest: None reported.

Orcid

Letícia de Sousa Silva

http://orcid.org/0000-0001-7002-038X

Jonathas Rodrigues Siqueira Costa

iD http://orcid.org/0000-0001-5893-9369

Liliane de Sousa Silva

iD http://orcid.org/0000-0001-9497-7573

Carla Rosane Mendanha da Cunha

(iD) http://orcid.org/0000-0003-1497-1417

How to cite this article

APA

Silva, L. S., Costa, J. R. S., Silva, L. S., \& Cunha, C. R. M. (2020). Retrospective study of the situation of Brazilian countryside schools and conceptions of teachers of rural public schools in the municipality of Itapuranga, Goiás, Brazil. Rev. Bras. Educ. Camp., 5, e9036. http://dx.doi.org/10.20873/uft.rbec.e9036

ABNT

SILVA, L. S.; COSTA, J. R. S.; SILVA, L. S.; CUNHA, C. R. M. Retrospective study of the situation of Brazilian countryside schools and conceptions of teachers of rural public schools in the municipality of Itapuranga, Goiás, Brazil. Rev. Bras. Educ. Camp., Tocantinópolis, v. 5, e9036, 2020. http://dx.doi.org/10.20873/uft.rbec.e9036 